\title{
Aktivitas Antibakteri Ekstrak Alga Merah dari Pantai Luk, Sumbawa terhadap Salmonella thypi dan Staphylococcus aureus
}

\author{
Antibacterial Activity of Red Algae Extracts from Luk Beach, Sumbawa against Salmonella \\ thypi and Staphylococcus aureus
}

\author{
Yulianti $^{1 *}$, Asmawati ${ }^{1}$, Yunianti ${ }^{1}$, Baso Manguntungi ${ }^{1}$ \\ ${ }^{1}$ Program Studi Teknobiologi, Fakultas Teknobiologi, Universitas Teknologi Sumbawa \\ E-mail: yulianti.biotek@gmail.com *Penulis untuk korespondensi
}

\begin{abstract}
Indonesia is a maritime country with abundant marine resources. One of them is algae which spread almost all over Indonesian waters including in sea area of Luk, Sumbawa. The type of potential algae that has the greatest number of primary and secondary metabolite coumpounds is the red algae. This research aims to discover antibacterial activity of rough extract of red algae from Luk beach. The study included the identification of red algae based on morphological characteristics, followed by extracting red algae using maceration method with aquadest solvent previously performed in three sample preparations ie drying $\left(27{ }^{\circ} \mathrm{C}\right)$, heating $\left(70-80{ }^{\circ} \mathrm{C}\right)$ and cooling $\left(-10{ }^{\circ} \mathrm{C}\right)$, each tested with concentration $20,40,60,80$ and $100 \%$ were then tested in vitro against Salmonella thypi and Staphylococcus aureus. The results of the identification of three species of red algae obtained from Luk beach were Gracilaria salicornia, Galaxaura sp, and Halymenia sp. Antibacterial test of rhodophyta showed different inhibitory zones in each species against both pathogenic bacteria. Each rough extract of red algae has different optimum extract preparation method. The largest inhibitory zone of Gracilaria salicornia extract to $S$. thypi on drying method with $100 \%$ concentration and to $S$. aureus on cooling method with $60 \%$ concentration; extract of Galaxaura sp to $S$. thypi on cooling method $(\mathbf{1 0 0 \%})$, to $S$. aureus on drying method $(\mathbf{8 0 \%})$; extract of Halymenia sp to $S$. thypi on heating method $(40 \%)$, to $S$. aureus on heating method $(80 \%)$.
\end{abstract}

Keywords: red algae, antibacterial, $S$. thypi, $S$. aureus, Luk beach

\begin{abstract}
Abstrak
Indonesia termasuk negara maritim yang memiliki sumber kekayaan alam laut yang melimpah. Salah satunya yaitu alga yang persebarannya hampir di seluruh perairan Indonesia termasuk di kawasan laut Luk, Sumbawa. Jenis alga potensial yang memiliki paling banyak kandungan senyawa metabolit primer dan sekunder adalah alga merah. Penelitian ini dilakukan bertujuan untuk mengetahui aktivitas antibakteri ekstrak kasar alga merah dari pantai Luk. Penelitian ini meliputi pengidentifikasian alga merah berdasarkan ciri morfologi, dilanjutkan dengan mengekstraksi alga merah menggunakan metode maserasi dengan pelarut akuades yang sebelumnya dilakukan tiga preparasi sampel yaitu pengeringan $\left(27^{\circ} \mathrm{C}\right)$, pemanasan $\left(70-80{ }^{\circ} \mathrm{C}\right)$ dan pendinginan $\left(-10{ }^{\circ} \mathrm{C}\right)$, masing-masing diuji dengan konsentrasi $20 \%, 40 \%, 60 \%, 80 \%$ dan $100 \%$ kemudian diuji secara in vitro terhadap Salmonella thypi dan Staphylococcus aureus. Hasil identifikasi dari tiga spesies alga merah yang didapatkan dari pantai Luk yaitu Gracilaria salicornia, Galaxaura sp, dan Halymenia sp. Pengujian antibakteri alga merah menunjukkan zona hambat yang berbeda pada setiap spesies terhadap kedua bakteri patogen. Masing-masing ekstrak kasar alga merah memiliki metode preparasi ekstrak optimal yang berbeda. Zona hambat terbesar dari ekstrak Gracilaria salicornia terhadap S. thypi pada metode pengeringan dengan konsentrasi $100 \%$ dan terhadap $S$. aureus pada metode pendinginan dengan konsentrasi 60\%. Ekstrak Galaxaura sp terhadap $S$. thypi pada metode pendinginan (100\%), terhadap $S$. aureus pada metode pengeringan $(\mathbf{8 0} \%)$. Ekstrak Halymenia sp terhadap $S$. thypi pada metode pemanasan $(40 \%)$, terhadap S. aureus pada metode pemanasan $(80 \%)$.
\end{abstract}

Kata kunci: alga merah, antibakteri, S. thypi, S. aureus, pantai Luk

Diterima: 1 Februari 2018, disetujui: 20 Februari 2018 


\section{Pendahuluan}

Indonesia merupakan negara maritim dengan perbandingan luas wilayah lautan dan daratan berbanding 3:1, karena hampir $70 \%$ luas wilayahnya berupa lautan yang memiliki sumber daya alam laut yang melimpah dan beragam baik hayati maupun nonhayati (Alfiyaturohmah dkk., 2014). Salah satu sumber daya alam yang cukup potensial dari perairan laut Indonesia adalah alga (Andriani dkk., 2015). Penyebaran alga terdapat hampir di seluruh perairan Indonesia termasuk di kawasan Laut Luk, Sumbawa.

Alga digunakan sebagai bahan makanan, minuman, kosmetik, dan obat-obatan. Alga juga memiliki kemampuan untuk memproduksi metabolit sekunder yang bersifat sebagai senyawa bioaktif untuk melindungi dirinya dari kondisi lingkungan hidup yang ekstrim seperti salinitas tinggi dan pertahanan diri dari ancaman berbagai penyakit dan predator (Sareong, 2008). Jumlah dan variasi senyawa bioaktif alga sangat banyak dan beragam. Senyawa bioaktif dari alga telah ditemukan penggunaannya sebagai antibakteri (Maduriana dan Sudira, 2009), antioksidan (Suryaningrum dkk., 2006), antijamur (Lutfiyanti dkk., 2012), antikanker (Nurmareta, 2014), dan antiinflamasi (Ariani, 2015).

Alga terdiri atas tiga kelas, yaitu Rhodophyceae (alga merah), Phaeophyceae (alga cokelat), dan Chlorophyceae (alga hijau). Jenis alga yang paling banyak jumlahnya ditemukan di Indonesia yaitu alga merah terdiri dari 452 jenis (Moosa, 1999). Alga merah (Rhodophyta) merupakan salah satu kelas dari alga yang memiliki pigmen dominan berwarna merah (Marianingsih dkk., 2013) yang disebabkan oleh pigmen fikobilin berupa allofikosianin, fikoeritrin, dan fikosianin yang menutupi karakter warna dari klorofil (Oryza dkk., 2017). Dibandingkan dengan alga hijau dan coklat, alga merah merupakan jenis alga yang paling banyak mengandung senyawa metabolit primer dan sekunder (Amaranggana dan Wathoni, 2017). Senyawa bioaktif yang diisolasi dari alga merah termasuk alkaloid, poliketida, peptide siklik, polisakarida, phlorotannin, diterpenoid, sterol, quinine (Srikong dkk., 2015), terpenoid, asetogenik, dan senyawa aromatik (Simanjuntak, 1995).
Alga merah yang kaya akan senyawa metabolit ini menjadi potensi yang dapat dimanfaatkan sebagai salah satu upaya untuk mengungkapkan sifat biologis dan medis dari flora laut serta mengoptimalkan pemanfaatan bahan alam laut Indonesia khususnya di daerah Sumbawa, yang memungkinkan kelompok tersebut menjadi kandidat baru dalam dunia farmasi khususnya dalam penanganan terhadap bakteri patogen yang saat ini telah banyak menunjukkan sifat resisten terhadap antibiotik (Nurmala, 2015). Maka pada penelitian ini dilakukan pengujian aktivitas antibakteri terhadap $S$. thypi dan $S$. aureus dengan pertimbangan bahwa $S$. thypi merupakan bakteri Gram negatif, sedangkan $S$. aureus merupakan bakteri Gram positif. Kedua bakteri tersebut merupakan jenis bakteri patogen yang tersebar luas di tubuh manusia dan biasa menyebabkan infeksi (Ekawati dkk., 2018).

Pengujian aktivitas antibakteri dari ekstrak kasar alga merah dengan pelarut akuades ini dilakukan dengan beberapa preparasi sampel yang dapat digunakan sebagai alternatif yang lebih mudah dalam mempermudah proses penggerusan. Sifat substansi thalus alga yang beranekaragam, ada yang lunak karena tingginya gelatin dan keras karena mengandung zat kapur, yang menyebabkan beberapa jenis tidak mudah dihancurkan (Suparmi dan Sahri, 2009). Tujuan dilakukan penelitian ini adalah untuk mengetahui jenis alga merah yang ada di Pantai Luk Sumbawa dan metode preparasi terbaik yang dapat digunakan untuk mengoptimalkan proses ekstraksi alga merah dilihat dari zona hambat yang dihasilkan.

\section{Metode Penelitian}

\section{Lokasi dan Waktu Penelitian}

Penelitian ini dilaksanakan pada bulan Desember 2017 - Januari 2018. Pengambilan sampel alga dari Pantai Luk, Sumbawa. Ekstraksi dan uji aktivitas antibakteri dilakukan di Laboratorium Mikrobiologi, Fakultas Teknobiologi, Universitas Teknologi Sumbawa.

\section{Alat dan Bahan \\ Alat yang digunakan dalam penelitian ini adalah mortal pistil (Cole-Parmer), hot plate}


(Iwaki Ecan HPS-2002), mikropipet (Thermo Scientific), Biosafety Cabinet (BioBase 11231BBC 86), inkubator (Memmert IN75), seperangkat alat kaca (Pyrex Iwaki) (gelas beaker, gelas ukur, labu erlenmeyer, batang pengaduk kaca, tabung reaksi, cawan petri), ose, rak tabung reaksi, tube falcon (Violamo), batang segitiga, timbangan (Precisa XT220A), autoclave (GEA YX-18LM), lemari pendingin (GEA), spatula, bunsen, dan pinset.

Bahan yang digunakan adalah sampel alga merah, biakan murni bakteri $S$. thypi dan $S$. aureus, media NB (Nutrient Broth), agar, akuades, kertas cakram, alumunium foil, kapas, alkohol 70\%, tissue, sarung tangan lateks, masker.

\section{Tahapan Penelitian}

\section{Pengambilan Sampel}

Sampel diambil di perairan Laut Luk, Sumbawa dan pengambilan sampel dilakukan saat air laut mencapai surut. Sampel yang digunakan adalah alga merah yang tanpa memperhatikan umur tumbuhan. Sampel yang telah diambil dibersihkan dari substratnya dan dicuci hingga bersih (Sukmawaty dkk., 2016).

\section{Identifikasi Alga Merah}

Identifikasi dari setiap genus dan spesies yang didapatkan, didasarkan pada pengamatan morfologi dan pedoman praktis identifikasi alga laut (Atmaja, dkk., 1996; Trono, 1997).

\section{Ekstraksi Sampel}

Sampel yang telah dibersihkan selanjutnya masing-masing jenis alga diberlakukan dengan tiga metode berbeda yaitu dibekukan pada suhu $10{ }^{\circ} \mathrm{C}$ selama 24 jam, dipanaskan selama 1 jam pada suhu $70-80{ }^{\circ} \mathrm{C}$, dan dikeringkan dengan cara dijemur tanpa penyinaran matahari secara langsung selama 4 hari untuk menghindari berubah atau rusaknya komponen senyawa bioaktif yang terdapat pada sampel. Alga merah kemudian dihaluskan mengunakan mortar pistil guna memecah dinding sel sampel dan memperluas permukaan sampel, sehingga mempermudah kontak antara pelarut dan sampel, senyawa bioaktif yang terdapat dalam sampel dapat terbawa sempurna saat ekstaksi maserasi (Setyati dkk., 2017). Kemudian dimaserasi dengan menggunakan pelarut air/akuades steril dengan perbandingan 1:1 selama $2 \times 24$ jam pada $27{ }^{\circ} \mathrm{C}$. Hasil maserasi dipisahkan antara filtrat dan residunya dengan penyaringan, sehingga diperoleh ekstrak kasar.

\section{Peremajaan Bakteri Uji}

Bakteri Salmonella thyphi dan Staphylococcus aureus yang berasal dari biakan murni, masing-masing diambil sebanyak satu ose kemudian ditumbuhkan atau diinokulasikan dengan cara digores pada medium Nutrient Agar (NA) miring. Kultur bakteri pada agar miring diinkubasi pada suhu $37{ }^{\circ} \mathrm{C}$ selama 24 jam (Nurwahida, 2018).

\section{Pembuatan Suspensi Bakteri Uji}

Bakteri uji yang telah diremajakan selama 24 jam, masing-masing diambil satu ose kemudian disuspensikan ke dalam media Nutrient Broth (NB), setelah itu dihomogenkan. Kultur cair diinkubasi pada suhu $37{ }^{\circ} \mathrm{C}$ selama 24 jam (Nuria, 2010). Kekeruhan pada media diamati yang menandakan adanya perbanyakan sel bakteri (Lestari dkk., 2014).

\section{Penyiapan Bahan Ekstrak Alga Merah dalam Berbagai Konsentrasi}

Ekstrak kasar dari ketiga metode berbeda dimasukkan dalam botol pengenceran masingmasing $200 \mu \mathrm{L}, 400 \mu \mathrm{L}, 600 \mu \mathrm{L}, 800 \mu \mathrm{L}$ dan $1000 \mu \mathrm{L}$. Selanjutnya ditambahkan dengan akuades steril hingga masing-masing larutan berjumlah $1 \mathrm{~mL}$. Hasil pengenceran tersebut diperoleh ekstrak dengan berbagai konsentrasi berbeda, masing-masing 20\%, 40\%, 60\%, $80 \%$ dan $100 \%$. Selanjutnya kelima konsentrasi ekstrak dalam botol tersebut dihomogenkan dengan cara digojok.

\section{Uji Aktivitas Antibakteri}

Uji aktivitas antibakteri dilakukan secara in vitro menggunakan uji sensitivitas antibakteri dengan metode difusi agar dengan menggunakan kertas cakram (Bachtiar dkk., 2012). Kertas cakram direndam dalam larutan ekstrak kasar dan larutan kontrol (akuades steril) masingmasing sebanyak 9 lembar selama 30 menit. Media pertumbuhan bakteri uji yang digunakan media NA. Sebanyak $100 \mu \mathrm{L}$ bakteri uji yang telah dikultur selama 24 jam diratakan menggunakan spreader/batang segitiga pada 
media pertumbuhan bakteri. Selanjutnya kertas cakram yang telah direndam pada masingmasing ekstrak dan kontrol negatif ditempelkan pada permukaan media NA yang telah diolesi suspensi bakteri. Letak kertas cakram pada permukaan media diatur sedemikian rupa dan tidak terlalu berdekatan agar zona hambat yang terbentuk nantinya tidak saling bertabrakan satu sama lainnya. Masing-masing perlakuan dengan tiga ulangan. Cawan petri kemudian diinkubasi pada suhu $37{ }^{\circ} \mathrm{C}$ selama 24 jam. Setelah masa inkubasi 24 jam, pertumbuhan bakteri dan zona bening yang timbul di sekitar kertas saring diukur diameternya. Diameter zona hambat ditentukan dengan cara mengurangi diameter keseluruhan (cakram + zona hambatan) dengan diameter cakram $(6 \mathrm{~mm})$ dan diameter zona hambat pelarut (jika pelarut memberikan zona hambatan) (Andriani dkk., 2015).

\section{Analisis Data}

Data yang telah diperoleh berupa nilai diameter zona hambat hasil uji aktivitas antibakteri yang diolah secara statistik dengan Analysis of Variance (ANOVA), apabila perlakuan yang diberikan menunjukkan pengaruh yang nyata, maka dilanjutkan dengan uji Jarak Berganda Duncan dengan taraf kepercayaan $95 \%$ yang bertujuan untuk mengetahui metode preparasi ekstrak dan konsentrasi perlakuan yang terbaik. Analysis of Variance (ANOVA) maupun uji Jarak Berganda Duncan dilakukan dengan menggunakan SPSS versi 16 (Bachtiar dkk., 2012).

\section{Hasil dan Pembahasan}

\section{Identifikasi Alga Merah}

Berdasarkan hasil penelitian didapatkan ciri-ciri sampel alga yang diketahui bahwa termasuk kelompok alga merah yang ada di Pantai Luk berjumlah 3 jenis. Klasifikasi 3 jenis alga merah yang ditemukan dapat dilihat pada Tabel 1 .

Tabel 1. Klasifikasi Rhodophyta di Pantai Luk, Sumbawa.

\begin{tabular}{|c|c|c|c|c|}
\hline Telas & Ordo & Famili & Genus & Spesies \\
\hline 1 Florideophyceae & "Glacilariales & Gracilariaceae & Gracilaria & Gracilaria salicornia \\
\hline 2 Florideophyceae & Nemaliales & Galaxauraceae & Galaxaura & Galaxaura sp. \\
\hline 3 Florideophyceae & Halymeniales & Halymeniaceae & Halymenia & Halymenia sp. \\
\hline
\end{tabular}

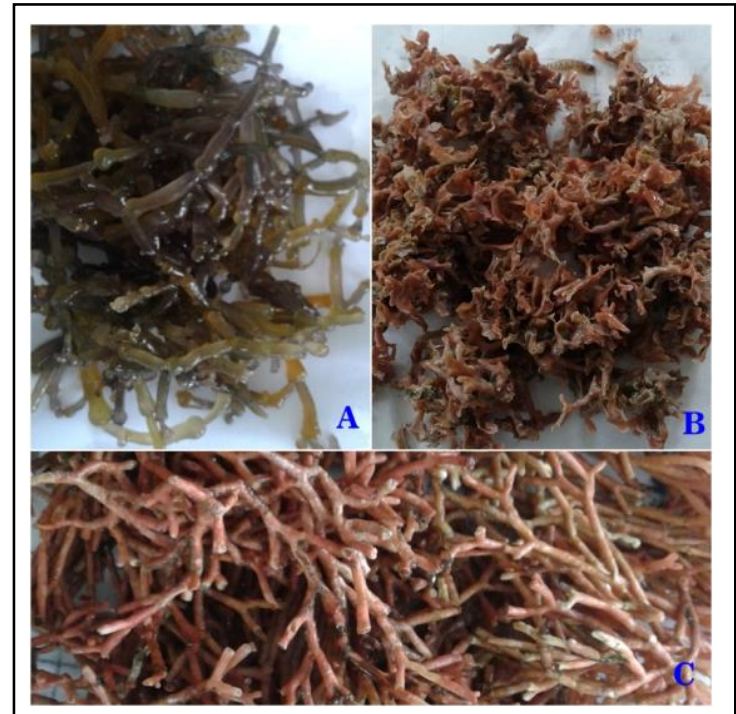

Gambar 1. Alga merah di Pantai Luk. A. Gracilaria salicornia, B. Halymenia sp, C. Galaxaura sp. (Sumber: Dok. Pribadi, 2017). 
Identifikasi jenis alga anggota divisi alga merah yang ditemukan di Pantai Luk diidentifikasi dengan pengamatan karakter morfologi. Struktur morfologis alga merah mulai dari bentuk filament, bercabang, berbentuk bulu, dan lembaran. Pengamatan karakter ini lebih cepat dan lebih mudah untuk dilakukan dalam identifikasi (Oryza dkk., 2017). Hasil identifikasi karakter morfologi adalah sebagai berikut:

Gracilaria salicornia, bentuk talus bulat, licin, berbuku-buku atau bersegmen-segmen, berbentuk rumpun. Percabangan talus berbentuk polystichous atau banyak cabang pada talus utama. Bentuk holdfast yang melekat pada substrat yaitu rhizoid. Alga ini memiliki warna talus hijau dan kuning di bagian apeks thalli. Habitatnya pada karang, berpasir dan di daerah rataan terumbu karang yang tumbuh menempel. Spesies alga ini biasanya ditemukan pada daerah pasang surut. Sering terdampar ke pantai karena tidak kuat menempel pada substrat sehingga mudah terbawa oleh ombak (Langoy dkk., 2011).

Galaxaura sp., holdfast tipe rhizoid, talus berbentuk pipih, talus berwarna merah dengan bagian ujung berwarna merah muda hingga kuning. Percabangan dichotomous, sekat terlihat di beberapa bagian. Bagian ujung tidak terlihat berlubang karena talus pipih. Jenis alga ini ditemukan pada karang dan pasir, talus dapat mencapai tinggi 9-10 cm (Oryza dkk., 2017).

Halymenia sp, memiliki talus yang gepeng, licin, bergelatin, warna merah tua atau merah muda. Memiliki percabangan berselang seling tak teratur pada kedua sisi talus. Talus bagian bawah biasanya melebar dan mengecil ke bagian puncak. Ujung talus Halymenia sp bercabang, rimbun, dan bergerigi (Handayani dkk., 2014).

\section{Preparasi Sampel dan Ekstraksi Alga Merah}

Sampel yang digunakan dalam penelitian ini adalah alga merah yang diperoleh dari Pantai Luk, Sumbawa. Sampel diberi perlakuan berbeda pada tahap preparasi sampel yaitu sampe dikeringkan, dibekukan, dan dipanaskan. Sampel dikeringkan untuk menurunkan kadar air. Pengeringan dilakukan pada suhu $27{ }^{\circ} \mathrm{C}$ bertujuan untuk meminimalisir kadar air yang terkandung dalam alga sehingga menghambat aktivitas mikroorganisme (jamur maupun bakteri) dan menghindari kerusakan senyawa aktif pada sampel yang tidak tahan panas (Alfiyaturohmah dkk., 2014). Sampel dibekukan pada suhu $-10{ }^{\circ} \mathrm{C}$ untuk mempermudah proses penghalusan dan mendapatkan ekstrak dari alga segar, sedangkan dipanaskan pada suhu $70-80{ }^{\circ} \mathrm{C}$ bertujuan untuk membantu merusak dinding sel alga sehingga mempermudah proses ekstraksi.

Penghalusan dilakukan dengan tujuan memperluas permukaan sampel, sehingga mempermudah kontak antara pelarut dan sampel pada saat ekstraksi maserasi. Ekstraksi senyawa aktif alga merah menggunakan metode maserasi dengan pelarut air/akuades. Metode maserasi dipilih karena metode ini menguntungkan dalam isolasi bahan alam disebabkan karena dengan perendaman, sampel alga akan mengalami pemecahan dinding dan membran sel akibat perbedaan tekanan antara di dalam dan di luar sel sehingga metabolit sekunder yang ada di dalam sitoplasma akan terlarut dalam pelarut (Hanapi dkk., 2013). Penggunaan pelarut air pada proses ekstraksi senyawa aktif pada alga dikarenakan air bersifat polar. Menurut Suryaningrum dkk. (2006) ekstrak senyawa bioaktif lebih banyak yang bersifat polar daripada nonpolar pada beberapa spesies alga seperti Halymenia harveyana dan Eucheuma cottoni. Selain itu, di antara pelarut yang sifatnya polar, air dapat dikatakan paling aman dan mudah didapatkan.

\section{Aktivitas Antibakteri dari Ekstrak Kasar Alga Merah Gracillaria salicornia}

Uji aktivitas antibakteri merupakan metode pengujian yang dilakukan untuk mengetahui kemampuan suatu bahan dalam menghambat pertumbuhan bakteri (Andriani dkk., 2015). Pengujian ini dilakukan terhadap bakteri $S$. thypi (Gram negatif) dan bakteri $S$. aureus (Gram positif) secara in vitro dengan metode difusi cakram. Penentuan zona hambat dilakukan dengan cara mengamati zona bening yang berada di zona terluar kertas cakram yang mengandung ekstrak alga merah pada media agar yang telah ditumbuhi bakteri. Semakin besar zona hambat maka semakin besar pula kemampuan ekstrak alga merah dalam menghambat pertumbuhan bakteri. 
Hasil pengamatan uji antibakteri setelah masa inkubasi 24 jam (Tabel 2) menunjukkan bahwa preparasi sampel terbaik yang digunakan untuk menghasilkan zona hambat dari ekstrak kasar alga merah Gracillaria salicornia terhadap Salmonella thypi dengan metode pengeringan dibandingkan dengan hasil dari preparasi pemanasan dan pendinginan. Konsentrasi pengenceran ekstrak berpengaruh nyata $(\mathrm{p}<0,05)$ terhadap pertumbuhan bakteri $S$. thypi dan $S$. aureus. Konsentrasi terbaik yaitu $100 \%$ menggunakan metode pengeringan sebesar 11,67 mm yang sangat berbeda nyata terhadap kontrol, pada metode pemanasan konsentrasi terbaik yaitu $80 \%$ sebesar $8,33 \mathrm{~mm}$ yang juga sangat berbeda nyata terhadap kontrol, sedangkan pendinginan, aktivitas antibakteri terlihat hanya pada konsentrasi $20 \%$ yaitu sebesar 3,33 mm yang berbeda nyata terhadap kontrol. Berbeda halnya pengujian pada Staphylococcus aureus menunjukkan preparasi sampel terbaik adalah pendinginan dengan konsentrasi $60 \%$ sebesar 2,33 mm dibandingkan dengan metode preparasi lainnya.

Hasil zona hambat dari ekstrak kasar $G$. salicornia menunjukkan kemampuan menghambat pertumbuhan bakteri yang lebih besar terhadap $S$. thypi dibandingkan dengan $S$. aureus pada metode pengeringan dan pemanasan. Tiap ekstrak kasar dengan masingmasing metode preparasi memiliki kemampuan berbeda dalam menghambat pertumbuhan bakteri, hal ini diduga karena pada proses preparasi juga menentukan dapat tidaknya senyawa aktif terekstraksi secara maksimal. Metode pengeringan lebih mempermudah proses penghalusan daripada pada metode pemanasan dan pendinginan. Perbedaan ini disebabkan karena dalam keadaan segar, G. salicornia mempunyai thalus lebih tebal yang mengandung massa yang lebih banyak serta tekstur yang kenyal sehingga pada proses penghalusan, sampel yang dikeringkan terlebih dahulu dapat menghilangkan tekstur alga yang kenyal, lebih mudah dihaluskan dibandingkan dengan sampel yang dipanaskan dan didinginkan karena teksturnya yang tidak berubah. Penghalusan bertujuan memperluas permukaan sampel, sehingga mempermudah kontak antara pelarut dan sampel pada saat ekstraksi maserasi (Andriani dkk., 2015).
Perbedaan kemampuan penghambatan juga dilihat dari perbedaan sifat antara bakteri uji. Bakteri Gram positif dan bakteri Gram negatif memiliki sifat dan respon berbeda terhadap senyawa antibakteri. S. aureus termasuk dalam bakteri Gram positif lebih sensitif terhadap senyawa antibakteri yang bersifat nonpolar. Sebaliknya S. thypi termasuk bakteri Gram negatif lebih sensitif terhadap senyawa antibakteri yang bersifat polar. Perbedaan respon tersebut disebabkan oleh komponen dasar penyusun dinding sel bakteri Gram positif yaitu peptidoglikan yang salah satu penyusunnya adalah asam amino alanin yang bersifat hidrofobik (nonpolar). Dinding sel bakteri Gram negatif terdiri dari tiga komponen yaitu lipoprotein membran terluar yang mengandung molekul protein yang disebut porin dan lipopolisakarida. Porin pada membran terluar dinding sel bakteri Gram negatif tersebut bersifat hidrofilik (polar) (Sareong, 2008). Kemampuan daya hambat yang lebih besar pada S. thypi yang merupakan bakteri Gram negatif kemungkinan disebabkan oleh persamaan sifat dari porin dan komponen ekstrak, dimana porin dan ekstrak sama-sama bersifat hidrofilik (polar). Hal ini didukung oleh pengujian aktivitas antibakteri alga merah terhadap beberapa jenis pelarut dilakukan oleh Andriani dkk. (2015) yang menunjukkan hasil bahwa ekstrak metanol memiliki aktivitas tertinggi yang diikuti dengan ekstrak n-heksana dan kloroform. Hal ini mengindikasi bahwa senyawa aktif pada alga merah cenderung bersifat polar.

Terbentuknya zona hambat menunjukkan kandungan metabolit sekunder alga merah berpotensi sebagai antibakteri. Gracillaria menghasilkan senyawa bioaktif seperti steroid, terpenoid, dan asam eicosanoid (Kasanah dkk., 2015). Menurut Pramesti dkk. (2017) golongan senyawa tersebut memiliki mekanisme penghambatan bakteri dengan meningkatkan permeabilitas sel yang berakibat pada kerusakan membran sel bakteri, sehingga terjadi kebocoran sel yang diikuti keluarnya material intraseluler.

\section{Aktivitas Antibakteri dari Ekstrak Kasar Alga Merah Galaxaura sp}

Hasil uji ANOVA dari ekstrak Galaxaura $\mathrm{sp}$ berpengaruh nyata $(\mathrm{p}<0,05)$ terhadap pertumbuhan bakteri $S$. thypi dan $S$. aureus. 
Preparasi sampel dari ekstrak kasar alga merah Galaxaura sp dalam menghambat pertumbuhan bakteri Salmonella thypi dari hasil pengamatan setelah inkubasi 24 jam yaitu pada metode pendinginan pada konsentrasi $100 \%$ sebesar 2,33 mm. Sedangkan pengujian ekstrak kasar terhadap $S$. aureus metode yang menunjukkan zona hambat terbesar yaitu pengeringan dengan konsentrasi $80 \%$ sebesar $4,33 \mathrm{~mm}$ yang berbeda sangat nyata terhadap kontrol. Kontrol yang digunakan yaitu kertas cakram yang mengandung pelarut akuades tanpa ekstrak alga merah pada media agar yang ditumbuhi bakteri, terdapat pertumbuhan koloni bakteri $S$. thypi dan $S$. aureus dan tidak ada zona hambat yang terbentuk. Hal ini menunjukkan pelarut akuades yang digunakan pada pengenceran ekstrak alga merah tidak bersifat bakterisidal terhadap bakteri uji, terbukti dengan pertumbuhan normal dan tidak adanya zona hambat pada kontrol. Selain itu juga sebagai indikator pertumbuhan bakteri uji secara normal pada berbagai perlakuan dan tidak terkontaminasi oleh bakteri lain (Bachtiar dkk., 2012).

Tabel 2. Hasil Pengamatan Aktivitas Antibakteri Gracillaria salicornia

\begin{tabular}{|c|c|c|}
\hline \multirow{2}{*}{ Perlakuan } & \multicolumn{2}{|c|}{ Diameter Zona Hambat (mm) } \\
\hline & S. thypi & S. aureus \\
\hline Kontrol (0) & $0,00^{\mathrm{a}}$ & $0,00^{\mathrm{a}}$ \\
\hline Pengeringan $20 \%$ & $1,00^{\mathrm{ab}}$ & $1,33^{\text {bcde }}$ \\
\hline Pengeringan $40 \%$ & $8,67^{\mathrm{cd}}$ & $1,00^{\mathrm{abcd}}$ \\
\hline Pengeringan $60 \%$ & $3,67^{\mathrm{ab}}$ & $0,00^{\mathrm{a}}$ \\
\hline Pengeringan $80 \%$ & $10,33^{\mathrm{d}}$ & $1,33^{\text {bcde }}$ \\
\hline Pengeringan $100 \%$ & $11,67^{\mathrm{d}}$ & $1,67^{\text {cde }}$ \\
\hline Pemanasan 20\% & $0,00^{\mathrm{a}}$ & $0,67^{\mathrm{abc}}$ \\
\hline Pemanasan $40 \%$ & $5,00^{\mathrm{bc}}$ & $1,00^{\mathrm{abcd}}$ \\
\hline Pemanasan $60 \%$ & $0,00^{\mathrm{a}}$ & $1,33^{\text {bcde }}$ \\
\hline Pemanasan $80 \%$ & $8,33^{\mathrm{cd}}$ & $0,33^{\mathrm{ab}}$ \\
\hline Pemanasan $100 \%$ & $0,00^{\mathrm{a}}$ & $0,33^{\mathrm{ab}}$ \\
\hline Pendinginan $20 \%$ & $3,33^{\mathrm{ab}}$ & $2,00^{\mathrm{de}}$ \\
\hline Pendinginan $40 \%$ & $0,00^{\mathrm{a}}$ & $2,00^{\mathrm{de}}$ \\
\hline Pendinginan $60 \%$ & $0,00^{\mathrm{a}}$ & $2,33^{\mathrm{e}}$ \\
\hline Pendinginan $80 \%$ & $0,00^{\mathrm{a}}$ & $2,00^{\mathrm{de}}$ \\
\hline Pendinginan $100 \%$ & $0,00^{\mathrm{a}}$ & $1,67^{\text {cde }}$ \\
\hline
\end{tabular}

Keterangan: uji analisis jarak berganda ducan dengan taraf kepercayaan 95\%. Rata-rata dari 3 ulangan.

Tabel 3. Hasil Pengamatan Aktivitas Antibakteri Galaxaura sp.

\begin{tabular}{|c|c|c|}
\hline \multirow{2}{*}{ Perlakuan } & \multicolumn{2}{|c|}{ Diameter Zona Hambat (mm) } \\
\hline & S. thypi & S. aureus \\
\hline Kontrol (0) & $0,00^{\mathrm{a}}$ & $0,00^{\mathrm{a}}$ \\
\hline Pengeringan $20 \%$ & $1,67^{\mathrm{bc}}$ & $1,00^{\mathrm{ab}}$ \\
\hline Pengeringan $40 \%$ & $1,33^{\mathrm{abc}}$ & $1,00^{\mathrm{ab}}$ \\
\hline Pengeringan $60 \%$ & $2,00^{\mathrm{bc}}$ & $4,00^{\mathrm{cd}}$ \\
\hline Pengeringan $80 \%$ & $0,00^{\mathrm{a}}$ & $4,33^{\mathrm{d}}$ \\
\hline Pengeringan $100 \%$ & $0,00^{\mathrm{a}}$ & $0,00^{\mathrm{a}}$ \\
\hline Pemanasan $20 \%$ & $0,00^{\mathrm{a}}$ & $0,67^{\mathrm{ab}}$ \\
\hline Pemanasan $40 \%$ & $0,00^{\mathrm{a}}$ & $2,33^{\text {abcd }}$ \\
\hline Pemanasan $60 \%$ & $0,00^{\mathrm{a}}$ & $1,33^{\mathrm{ab}}$ \\
\hline Pemanasan $80 \%$ & $0,00^{\mathrm{a}}$ & $3,00^{\text {bcd }}$ \\
\hline Pemanasan $100 \%$ & $0,67^{\mathrm{ab}}$ & $3,00^{\text {bcd }}$ \\
\hline Pendinginan $20 \%$ & $1,67^{\mathrm{bc}}$ & $1,67^{\mathrm{abc}}$ \\
\hline Pendinginan $40 \%$ & $2,00^{\mathrm{bc}}$ & $2,33^{\text {abcd }}$ \\
\hline Pendinginan $60 \%$ & $1,67^{\mathrm{bc}}$ & $2,67^{\mathrm{bcd}}$ \\
\hline Pendinginan $80 \%$ & $0,00^{\mathrm{a}}$ & $2,67^{\mathrm{bcd}}$ \\
\hline Pendinginan $100 \%$ & $2,33^{\mathrm{c}}$ & $2,67^{\mathrm{bcd}}$ \\
\hline
\end{tabular}

Keterangan: uji analisis jarak berganda ducan dengan taraf kepercayaan 95\%. Rata-rata dari 3 ulangan. 
Hasil zona hambat dari ekstrak kasar Galaxaura sp. menunjukkan kemampuan menghambat bakteri yang lebih besar terhadap $S$. aureus dibandingkan $S$. thypi baik pada metode pengeringan, pemanasan maupun pendinginan. Kemampuan biologis setiap bakteri juga berbeda-beda dalam merespon bahan antibakteri. Salah satu faktor yang paling berpengaruh terhadap hal tersebut adalah perbedaan struktur dinding sel antara bakteri Gram negatif dan Gram positif. Komponen yang dimiliki oleh bakteri Gram positif terdiri dari komponen asam teikhioat, asam teikhuronat, dan polisakarida. Sedangkan komponen bakteri Gram negatif terdiri atas lipoprotein, selaput luar, dan lipopolisakarida. Selaput luar dinding sel bakteri Gram negatif merupakan selaput ganda fosfolipid yang sebagian besar dianti dengan molekul lipopolisakarida. Selaput luar mempunyai sifat permeabilitas terhadap zat aktif yang ada tidak dapat masuk ke dalam sel bakteri, akibatnya bakteri sukar dirusak atau dihambat pertumbuhannya (Dali dkk., 2011). Sehingga pada pengujian ekstrak Galaxaura sp lebih aktif pada $S$. aureus (Gram positif) daripada S. thypi (Gram negatif).

Adanya zona hambat karena Galaxaura sp. mengandung metabolit sekunder yang berpotensi sebagai senyawa antibakteri yaitu senyawa flavonoid, saponin, glikosida, dan steroid/triterpenoid (Sagala, 2013). Golongan senyawa flavonoid sebagai antibakteri bekerja dengan merusak membran sel bakteri dan diikuti keluarnya senyawa intraseluler dengan cara membentuk senyawa kompleks dengan protein ekstraseluler dan terlarut. Selain itu, flavonoid juga berperan dalam inhibisi pada sintesis DNARNA dan dapat menghambat metabolisme energi (Ngajow dkk., 2013). Senyawa lain seperti saponin bekerja sebagai antibakteri dengan membuat kebocoran protein dan enzim dari dalam sel. Saponin memiliki zat aktif yang permukaannya mirip detergen, sehingga saponin dapat menurunkan tegangan permukaan dinding sel bakteri dan merusak permeabilitas membran (Ernawati dan Sari, 2015).

\section{Aktivitas Antibakteri dari Ekstrak Kasar Alga Merah Halymenia sp.}

Hasil uji ANOVA dari ekstrak Halymenia sp. berpengaruh nyata $(\mathrm{p}<0,05)$ terhadap pertumbuhan S. thypi dan S. aureus. Hasil pegamatan zona hambat dari ekstrak kasar alga merah Halymenia sp terhadap S. thypi setelah inkubasi selama 24 jam menunjukkan metode preparasi pemanasan dengan konsentrasi $40 \%$ yang menunjukkan kemampuan penghambatan paling tinggi dengan diameter $15,00 \mathrm{~mm}$. Sama halnya pada $S$. aureus metode preparasi dengan hasil zona hambat terbesar yaitu pemanasan dengan konsentrasi 80\% sebesar 3,67 $\mathrm{mm}$. Kemampuan senyawa aktif Halymenia sp dalam menghambat $S$. aureus tidak berbeda jauh pada S. thypi tetapi lebih luas menghambat pada metode pengeringan. Seperti halnya pada penelitian yang dilakukan Rahelivao dkk. (2015), ekstrak metanol dari Halymenia sp. ditemukan sangat aktif terhadap Staphylococcus aureus dan Streptococcus pneumoniae, tetapi kurang aktif terhadap Bacillus cereus, dan tidak aktif terhadap Enterobacter cloacae, Klebsiella oxytoca, Escherichia coli, Salmonella enteridis, dan Candida albicans.

Halymenia sp. berpotensi sebagai antibakteri. Hal tersebut terkait dengan sebagian besar senyawa yang ditemukan pada Halymenia berasal dari kelompok asam lemak yang menunjukkan aktivitas antibakteri, antiinflamasi, dan antijamur dan alkane, asetat, amida, alkenil, alkohol serta kelompok steroid (Maheswari dan Reena, 2017). Penggunaan pelarut akuades pada proses ekstraksi kemungkinan menyebabkan kecilnya zona hambat yang dihasilkan karena tidak dapat melarutkan kelompok asam lemak tersebut.

Perbedaan zona hambat pada berbagai metode dan konsentrasi berbeda karena adanya perbedaan kandungan zat antibakteri terhadap masing-masing ekstrak, sehingga menyebabkan perbedaan kemampuan dalam menghambat pertumbuhan bakteri. Aktivitas antibakteri tergantung dari spesies alga dan efesiensi ekstraksi senyawa aktif (Hamza dkk., 2014). Selain itu, hal ini juga kemungkinan disebabkan oleh rendahnya konsentrasi kandungan zat aktif, resistensi dari bakteri terhadap substansi bioaktif serta jumlah inokulum bakteri atau kepadatan bakteri uji, sehingga ekstrak tersebut tidak dapat menghambat bakteri secara optimal. 
Yulianti dkk.,

Tabel 4. Hasil Pengamatan Aktivitas Antibakteri Halymenia sp.

\begin{tabular}{lcc}
\hline \multirow{2}{*}{ Perlakuan } & \multicolumn{2}{c}{ Diameter Zona Hambat (mm) } \\
\cline { 2 - 3 } & S. thypi & S. aureus \\
\hline Kontrol (0) & $0,00^{\mathrm{a}}$ & $0,00^{\mathrm{a}}$ \\
Pengeringan $20 \%$ & $1,67^{\mathrm{bc}}$ & $1,67^{\mathrm{bcd}}$ \\
Pengeringan $40 \%$ & $1,00^{\mathrm{ab}}$ & $3,33^{\mathrm{e}}$ \\
Pengeringan $60 \%$ & $1,67^{\mathrm{bc}}$ & $2,33^{\mathrm{cde}}$ \\
Pengeringan $80 \%$ & $1,33^{\mathrm{b}}$ & $2,33^{\mathrm{cde}}$ \\
Pengeringan $100 \%$ & $1,33^{\mathrm{b}}$ & $3,33^{\mathrm{e}}$ \\
Pemanasan $20 \%$ & $0,00^{\mathrm{a}}$ & $0,67^{\mathrm{ab}}$ \\
Pemanasan $40 \%$ & $15,00^{\mathrm{f}}$ & $1,33^{\mathrm{abcd}}$ \\
Pemanasan $60 \%$ & $0,00^{\mathrm{a}}$ & $0,67^{\mathrm{ab}}$ \\
Pemanasan $80 \%$ & $1,00^{\mathrm{ab}}$ & $3,67^{\mathrm{e}}$ \\
Pemanasan $100 \%$ & $0,00^{\mathrm{a}}$ & $0,33^{\mathrm{ab}}$ \\
Pendinginan $20 \%$ & $3,67^{\mathrm{a}}$ & $1,00^{\mathrm{abc}}$ \\
Pendinginan $40 \%$ & $0,00^{\mathrm{a}}$ & $1,33^{\mathrm{abcd}}$ \\
Pendinginan $60 \%$ & $2,00^{\mathrm{bcd}}$ & $1,67^{\mathrm{bcd}}$ \\
Pendinginan $80 \%$ & $2,67^{\mathrm{cde}}$ & $1,67^{\mathrm{bcd}}$ \\
Pendinginan $100 \%$ & $3,00^{\mathrm{de}}$ & $2,67^{\mathrm{de}}$ \\
\hline
\end{tabular}

Keterangan: uji analisis jarak berganda ducan dengan taraf kepercayaan 95\%. Rata-rata dari 3 ulangan.

\section{Simpulan}

Ada tiga spesies alga merah yang didapatkan di Pantai Luk, Sumbawa, yaitu Gracilaria salicornia, Galaxaura sp., Halymenia sp. Ketiga alga merah tersebut memiliki kemampuan antibakteri. Masing-masing memiliki metode preparasi ekstraksi terbaik untuk mengoptimalkan ekstrak senyawa aktif antibakteri pada alga merah. Zona hambat terbesar dari ekstrak Gracilaria salicornia terhadap $S$. thypi pada metode pengeringan dengan konsentrasi $100 \%$ dan terhadap S. aureus pada metode pendinginan konsentrasi $60 \%$. Ekstrak Galaxaura sp terhadap $S$. thypi pada metode pendinginan dengan konsentrasi $100 \%$, terhadap $S$. aureus pada metode pengeringan konsentrasi 80\%. Ekstrak Halymenia sp terhadap S. thypi pada metode pemanasan dengan konsentrasi $40 \%$, terhadap $S$. aureus pada metode pemanasan konsentrasi $80 \%$.

\section{Daftar Pustaka}

Alfiyaturohmah, Ningsih, R. dan Yusnawan, E. 2014. Uji Aktivitas Antibakteri Ekstrak Kasar Etanol, Kloroform dan N-Heksana Alga Coklat Sargassum vulgare Asal Pantai Kapong Pamekasan Terhadap Bakteri Staphilococcus aureus dan Eschericia coli. ALCHEMY: Journal of Chemistry, 3 (1): 57-66.
Amaranggana, L. dan Wathoni, N. 2017. Manfaat Alga Merah (Rhodopyta) sebagai Sumber Obat dari Bahan Alam. Majalah Farmasetika, 2 (1): 1619.

Andriani, Z., Fasya, A.G. dan Hanapi, A. 2015. Antibacterial Activity of the Red Algae Eucheuma cottonii Extract from Tanjung Coast, Sumenep Madura. ALCHEMY: Journal of Chemistry, 4 (2): 93-100.

Ariani, D.F. 2015. Identifikasi Efek Antiinflamasi Ekstrak Alga Coklat Padina sp terhadap Mencit. Skripsi. Fakultas Kedokteran Gigi Universitas Hasanuddin. Makassar.

Atmaja, W.S., Kadi, A., Sulistijo dan Rachmaniar, S. 1996. Pengenalan Jenis-Jenis Rumput Laut Indonesia. Jakarta: Puslitbang Oseanologi LIPI.

Bachtiar, S.Y., Tjahjaningsih, W. dan Sianita, N. 2012. Pengaruh Ekstrak Alga Cokelat (Sargassum sp.) Terhadap Pertumbuhan Bakteri Escherichia coli. Journal of Marine and Coastal Science, 1 (1): 53-60.

Dali, S., Natsir, H., Usman, H. dan Ahmad, A. 2011. Bioaktivitas Antibakteri Fraksi Protein Alga Merah Gelidium amansii dari Perairan Cikoang Kabupaten Takalar, Sulawesi Selatan. Majalah Farmasi dan Farmakologi, 5(1): 47-52.

Ekawati, E.V., Husnul, S.N. dan Herawati, D. 2018. Identifikasi Kuman pada Pus dari Luka Infeksi Kulit. Jurnal SainHealth, 2 (1): 31-35.

Ernawati dan Sari, K. 2015. Kandungan Senyawa Kimia dan Aktivitas Antibakteri Ekstrak Kulit Buah Alpukat (Persea Americana P.Mill) terhadap Bakteri Vibrio alginolyticus. Jurnal Kajian Veteriner, 3(2): 203-211. 
Hamza, A.H., Al-Bishri, W., Omar, H.H. dan Danial, E.N. 2014. Potential Antimicrobial, Antioxidant and Anityrosenase Activities Achieved by Selected Species of Marine Macroalgae. Journal of Pure and Applied Microbiology, 8 (1): 257-265.

Hanapi, A., Fasya, A.G., Mardiyah, U. dan Miftahurrahmah. 2013. Uji Aktivitas Antioksidan dan Antibakteri Ekstrak Metanol Alga Merah Eucheuma spinosum. ALCHEMY: Journal of Chemistry, 2 (2): 126-137.

Handayani, S., Setia, T.M. dan Rahayu, S.E. 2014. Pengenalan Makroalga Indonesia. Jakarta: Dian Rakyat.

Kasanah, N., Triyanto, Seto, D.S., Amelia, W. dan Isnansetyo, A. 2015. Antibacterial Compounds from Red Seaweeds (Rhodophyta). Indones. J. Chem., 15 (2): 201-209.

Langoy, M.L.D., Saroyo, Dapas, F.N.J., Katili, D.Y. dan Hamsir, S.B. 2011. Deskripsi Alga Makro Di Taman Wisata Alam Batuputih, Kota Bitung. Jurnal Ilmiah Sains, 11 (2): 219-224.

Lestari, N., Roza, R.M. dan Martina, A. 2014. Analisis Fisiologi Bakteri Lignoselulolitik dan Aktinomisetes Selulolitik dan Ligninolitik dari Tanah Gambut Desa Rimbo Panjang Kabupaten Kampar sebagai Agen Biokompos. JOM FMIPA, 1 (2): 571-580.

Lutfiyanti, R., Ma'ruf, W.F. dan Dewi, E.N. 2012. Aktivitas Antijamur Senyawa Bioaktif Ekstrak Gelidium latifolium terhadap Candida albicans. Jurnal Pengolahan dan Bioteknologi Hasil Perikanan, 1 (1): 1-8.

Maduriana, I M. dan Sudira, I W. 2009. Skrining dan Uji Aktivitas Antibakteri Beberapa Rumput Laut dari Pantai Batu Bolong Canggu dan Serangan. Buletin Veteriner Udayana, 1 (2): 69-76.

Maheswari, U.M. dan Reena, A. 2017. Phytochemical Profiling of the Red Seaweed, Halymenia dilatata by GC-MS Analysis. International Journal of Pharma Sciences and Research, 8 (8): 167-172.

Marianingsih, P., Amelia, E. dan Suroto, T. 2013. Inventarisasi dan Identifikasi Makroalga di Perairan Pulau Untung Jawa. Prosiding Semirata FMIPA Universitas Lampung: 219223. Lampung, 10-12 Mei 2013: FMIPA Unila.

Moosa, M.K. 1999. Sumberdaya Laut Nusantara, Keanekaragaman Hayati Laut dan Pelestariannya. Loka Karya Keanekaragaman Hayati Laut. Pemanfaatan Secara Lestari Dilandasi Penelitian dan Penyelamatan. Widy Graha LIPI. Jakarta, 23 Februari 1999.

Ngajow, M., Abidjulu, J. dan Kamu, V.S. 2013. Pengaruh Antibakteri Ekstrak Kulit Batang Matoa (Pometia pinnata) terhadap Bakteri
Staphylococcus aureus secara In Vitro. Jurnal MIPA Unsrat Online, 2 (2): 128-132.

Nuria, M.C. 2010. Antibacterial Activities from Jangkang (Homalocladium platycladum (F.Muell) Bailey) Leaves. MEDIAGRO, 6 (2): 9-15.

Nurmala. 2015. Pola Bakteri, Resistensi dan Sensitivitasnya terhadap Antibiotik Berdasarkan Hasil Kultur pada Spesimen Pus di Rumah Sakit Umum Dokter Soedarso Pontianak Tahun 2011-2013. Laporan Penelitian. Fakultas Kedokteran Universitas Tanjungpura. Pontianak.

Nurmareta, Y. 2014. Uji Sitotoksik Ekstrak Alga Spirulina platensis terhadap Sel Kanker Leukemia P-388 dan Sel Kanker Payudara T47D. [Skripsi]. Fakultas Farmasi Universitas Muhammadiyah Purwokerto. Purwokerto.

Nurwahida. 2018. Uji Aktivitas Ekstrak Cacing Laut Perinereis aibuhitensis dalam Menghambat Pertumbuhan Bakteri Staphylococcus aureus dan Salmonella typhi. [Skripsi]. Fakultas Matermatika dan Ilmu Pengetahuan Alam Universitas Hasanuddin. Makassar.

Oryza, D., Mahanal, S. dan Sari, M.S. 2017. Identifikasi Rhodophyta sebagai Bahan Ajar Di Perguruan Tinggi. Jurnal Pendidikan: Teori, Penelitian, dan Pengembangan, 2 (3): 309-314.

Pramesti, R., Setyati, W.A. dan Zainuddin, M. 2017. Senyawa Metabolit Sekunder Rumput Laut Coklat Sargassum polycystum yang Berpotensi Sebagai Antibakteri Escherichia coli Multi Drug Resistent. Seminar Nasional Kelautan XII. Fakultas Teknik dan Ilmu Kelautan Universitas Hang Tuah. Surabaya, 20 Juli 2017.

Rahelivao, M.P., Gruner, M., Andriamanantoanina, H., Andriamihaja, B., Bauer, I. dan Knolker, H.J. 2015. Red Algae (Rhodophyta) from the Coast of Madagascar: Preliminary Bioactivity Studies and Isolation of Natural Products. Marine drugs, 13: 4197-4216.

Sagala, N.S. 2013. Skrining Fitokimia dan Uji Aktivitas Antibakteri Ekstrak n-Heksana dan Etilasetat serta Etanol Alga Merah (Galaxaura oblongata). [Skripsi]. Fakultas Farmasi Universitas Sumatera Utara. Medan.

Sareong, W. 2008. Uji Efektivitas Ekstrak Kasar Alga Merah Eucheuma cottonii sebagai Antibakteri terhadap Bakteri Patogen. [Skripsi]. Fakultas Matematika dan Ilmu Pengetahuan Alam Universitas Hasanuddin. Makassar.

Setyati, W.A., Pramesti, R., Zainuddin, M. dan Surur, M. 2017. Uji Konsentrasi Minimum Bakteriosidal (MBC) Staphylococcus aureus MDR pada Senyawa Bioaktif Ekstrak Rumput Laut Coklat Sragassum crassifolium dari Pulau Panjang Jepara. Seminar Nasional Kelautan XII. Universitas Hang Tuah. Surabaya. 
Yulianti dkk.,

Simanjuntak, P. 1995. Senyawa Bioaktif dari Alga. Hayati, 2 (2): 49-54.

Srikong, W., Mittraparp-arthorn, P., Rattanaporn, O., Bovornreungroj, N. dan Bovornreungroj, $\mathrm{P}$

2015. Antimicrobial Activity of Seaweed Extracts from Pattani, Southeast Coast of Thailand. Food and Applied Bioscience Journal., 3 (1): 39-49.

Sukmawaty, E., Masri, M., Putri, S. U. dan Nurzakiyah. 2016. Aktivitas Antibakteri Ekstrak dan Bakteri Endofit Makro Alga Caulerpa rasemosa L Asal Perairan Puntondo Terhadap Staphylococcus aureus dan Methicilin Resistant Staphylococcus aureus (MRSA). Prosiding Seminar Nasional from Basic Science to Comprehensive Education: 174-179. Makassar, 26 Agustus 2016: Fakultas Sains dan Teknologi UIN Alauddin Makassar.
Suparmi dan Sahri, A. 2009. Mengenal Potensi Rumput Laut: Kajian Pemanfaatan Sumber Daya Rumput Laut dari Aspek Industri dan Kesehatan. Sultan Agung, 44 (118): 95-116.

Suryaningrum, T.D., Wikanta, T. dan Kristiana, H. 2006. Uji Aktivitas Senyawa Antioksidan dari Rumput Laut Halymenia harveyana dan Eucheuma cottoni. Jurnal Pascapanen dan Bioteknologi Kelautan dan Perikanan, 1 (1): 51-63.

Trono, G.C. 1997. Field Guide and Atlas of the Seaweed Resources of the Philippines. Makati, Philippines: Bookmark. 